\title{
Effects of conjugated linoleic acid supplementation and feeding level on dairy performance, milk fatty acid composition, and body fat changes in mid-lactation goats
}

\author{
S. Ghazal, ${ }^{*} \dagger$ V. Berthelot, ${ }^{*} \dagger$ N. C. Friggens, ${ }^{*} \dagger$ and P. Schmidely ${ }^{*}{ }^{1}$ \\ ${ }^{*}$ AgroParisTech, UMR791 Modélisation Systémique Appliquée aux Ruminants, 16 rue Claude Bernard, F-75005 Paris, France \\ †INRA, UMR791 Modélisation Systémique Appliquée aux Ruminants, 16 rue Claude Bernard, F-75005 Paris, France
}

\begin{abstract}
The objective of this trial was to study the interaction between the supplementation of lipid-encapsulated conjugated linoleic acid (CLA; $4.5 \mathrm{~g}$ of cis-9,trans-11 $\mathrm{C} 18: 2$ and $4.5 \mathrm{~g}$ of trans-10,cis-12 C18:2) and feeding level to test if milk performance or milk fatty acid (FA) profile are affected by the interaction between CLA and feeding level. Twenty-four dairy goats were used in an 8 -wk trial with a 3 -wk adaptation to the experimental ration that contained corn silage, beet pulp, barley, and a commercial concentrate. During the third week, goats were assigned into blocks of 2 goats according to their dry matter intake (DMI), raw milk yield, and fat yield. Each block was randomly allocated to control (45 g of Ca salt of palm oil/d) or CLA treatment. Within each block, one goat was fed to cover 100\% (FL100) of the calculated energy requirements and the other was fed $85 \%$ of the DMI of the first goat (FL85). Individual milk production and composition were recorded weekly, and milk FA composition was analyzed in wk 3,5 , and 7. Conjugated linoleic acid supplementation reduced milk fat content and fat yield by 17 and 19\%, respectively, independent of the feeding level. It reduced both the secretion of milk FA synthesized de novo, and those taken up from the blood. No interaction between CLA and feeding level was observed on milk secretion of any group of FA. The CLA supplementation had no effect on DMI, milk yield, protein, and lactose yields but it improved calculated net energy for lactation balance. Goats fed the FL100 $\times$ CLA diet tended to have the highest DMI and protein yield. The interaction between CLA and feeding level was not significant for any other variables. Compared with the goats fed FL100, those fed FL85 had lower DMI, lower net energy for lactation balance, and lower digestible protein in the intestine balance. The body weight; milk yield; milk fat, protein, and lactose yields; and fat, protein, lactose, and urea
\end{abstract}

Received May 15, 2014.

Accepted July 15, 2014.

${ }^{1}$ Corresponding author: philippe.schmidely@agroparistech.fr contents in milk were not affected by feeding level. In conclusion, reduction in energy spared via fat yield reduction after CLA supplementation was not partitioned toward milk lactose or protein in goats at a low feeding level, possibly because of a simultaneous shortage of energy and amino acids. In goats on the high feeding level, energy spared tended to be partitioned toward milk protein yield, and at the same time to the prevention of excessive lipid mobilization.

Key words: conjugated linoleic acid, feeding level, milk fatty acid composition, goat

\section{INTRODUCTION}

The trans-10,cis-12 C18:2 isomer of CLA produced during ruminal biohydrogenation of cis-9,cis-12 C18:2 (Jenkins et al., 2008) is a potent inhibitor of milk fat synthesis in cows, inducing a downregulation of the abundance of transcript of key genes involved in de novo synthesis of FA, and decreases in the uptake of long-chain FA and in the desaturation of FA in the mammary gland of cows (Bauman et al., 2011). In cows, trans-10,cis-12 C18:2 induced a sharp reduction in milk fat yield up to 50\% (Bauman et al., 2011), whereas in dairy goats, similar doses of trans-10, cis-12 C18:2 as those used in cows decreased the fat yield by approximately $20 \%$, reflecting a lower sensitivity of the goat mammary gland to the antilipogenic effect of trans-10,cis-12 C18:2 (Shingfield et al. 2009; Ghazal et al., 2012).

When dietary energy supply to the mammary gland is limited by feed restriction, trans-10, cis-12 C18:2 may alter partitioning of the energy spared by fat yield depression to support an increase in other milk constituents, but results are inconsistent. Supplying trans-10, cis-12 C18:2 to cows or ewes fed 75 to $80 \%$ of their ME needs increased milk yield, lactose yield, and (or) protein yield in some studies (de Veth et al., 2006; Weerasinghe et al., 2012) but not in trials with cows fed restricted pasture (Kay et al., 2006) or ewes with low ME intake (Sinclair et al., 2007). These discrepancies were independent of the dietary protein availability, 
as no interactions between level of protein supply and trans-10, cis-12 C18:2 have been reported during feed restriction in cows and ewes fed moderate to high protein levels (de Veth et al., 2006; Weerasinghe et al., 2012). To date, no information is available on the response of milk production and composition to trans-10,cis-12 C18:2 in dairy goats fed at high or lower levels.

Decreases in fat yield caused by trans-10,cis-12 C18:2 may reduce total milk energy output, even if protein or lactose yields are increased during feed restriction (de Veth et al., 2006; Kay et al., 2006; Weerasinghe et al. 2012). As a consequence, trans-10,cis-12 C18:2 increased the calculated net energy balance (NEB), BW, and the expression of lipid synthesis enzymes in adipose tissues, reflecting the partitioning of spared energy away from milk toward adipose tissues (Harvatine et al., 2009). Additionally, trans-10,cis-12 C18:2 decreased the mobilization of the body mass fat during early lactation in the dairy cow (von Soosten et al., 2011, 2012). Conversely, trans-10,cis-12 C18:2 did not alter the weight of different adipose tissues, the chemical body composition, or lipid balance in earlylactation ewes (Sinclair et al., 2010). To our knowledge, no study has reported the effect of trans-10,cis-12 C18:2 on energy partitioning between milk and lipid storage in dairy goats fed at high or lower levels.

In consequence, the objective of the current study was to study the effect of the interaction between trans10,cis-12 C18:2 and the feeding level (FL) on milk performance and milk FA composition. We hypothesized that trans-10, cis-12 C18:2 may increase milk production or protein yield, or both, in dairy goats even in the case of limited energy intake, because of the anticipated reduction in energy need for milk fat synthesis.

\section{MATERIALS AND METHODS}

\section{Animals and Diets}

All experimental procedures were approved by the Animal Care Committee of Institut National de la Recherche Agronomique (INRA; Paris, France) in accordance with the Use of Vertebrates for Scientific Purposes Act of 1985. Twenty-four multiparous dairy Saanen $(\mathrm{n}=14)$ and Alpine $(\mathrm{n}=10)$ goats $(\mathrm{BW}=$ $71.5 \pm 8.3 \mathrm{~kg}, 30 \pm 2 \mathrm{DIM}$; mean $\pm \mathrm{SE}$ ) were used for $8 \mathrm{wk}$, with the first $3 \mathrm{wk}$ for adaptation to experimental diets. They were kept in individual pens and had free access to water and trace-mineralized salt blocks. At the initiation of the trial, the average milk yield was 4.1 $\pm 1 \mathrm{~kg} / \mathrm{d}$, with a milk fat content of $42.4 \pm 9.4 \mathrm{~g} / \mathrm{L}$ and a milk protein content of $33.6 \pm 5 \mathrm{~g} / \mathrm{L}$.

During the whole trial, goats were fed twice per day $(0800$ and $1700 \mathrm{~h})$ with two-thirds of their respective diet allocated in the afternoon and one-third in the morning, according to the time between milkings $(0730$ and $1630 \mathrm{~h}$ ). During the first 2 wk of the adaptation period, goats were progressively switched from their previous grass hay-based diet to a corn silage-based diet supplemented daily with $45 \mathrm{~g}$ of Ca salts of palm oil [control (CTL); Saphir Intense; Eolia-Tec, Bruz, France], and this diet was fed in wk 3. Throughout the experimental period (wk 4 to 8), all goats were fed a basal TMR containing corn silage $(35 \%$ on a DM basis), beet pulp (20\%), barley (15\%), and commercial concentrate (30\%; Fluvia Selectunic; Sanders Animal Nutrition, Pontivy, France). This commercial concentrate contained $18 \%$ maize, $14 \%$ sugar beet pulp, $12 \%$ sunflower meal, $10 \%$ wheat, $10 \%$ soybeans, $9 \%$ rapeseed meal, $6 \%$ soybean meal, $4 \%$ wheat distillers grains, $3.5 \%$ linseed, $3 \%$ pea seed, $1 \%$ rapeseed oil, $3 \%$ molasses, and $6.5 \%$ mineral and vitamin premix. It provided 1,630 Kcal of $\mathrm{NE}_{\mathrm{L}}$ and $200 \mathrm{~g}$ of $\mathrm{CP} / \mathrm{kg}$ of DM. The chemical composition and the nutritional value of the basal TMR is given in Table 1. A rather low CP was selected to decrease $\mathrm{N}$ wastes and to increase the efficiency of dietary $\mathrm{N}$ for milk output without a dramatic effect on milk protein secretion (Fernandez et al., 1997; Schmidely et al., 2002).

At the end of the third week, goats were assigned within breed into blocks of 2 goats according to their

Table 1. The chemical composition of the experimental $\operatorname{diet}^{1}$

\begin{tabular}{lc}
\hline Item & Amount \\
\hline Chemical composition, g/kg of DM & \\
OM & $947 \pm 0.6$ \\
CP & $119 \pm 0.2$ \\
Starch & $287 \pm 11.0$ \\
NDF & $296 \pm 3.7$ \\
ADF & $144 \pm 1.9$ \\
FA & $25 \pm 1.1$ \\
FA composition, g/100 g of total FA & \\
C14:0 & 0.2 \\
C16:0 & 14.6 \\
C18:0 & 2.1 \\
cis-9 C16:1 & 0.5 \\
cis-9 C18:1 & 28.3 \\
cis-9, cis-12 C18:2 & 43.4 \\
cis-9, cis-12, cis-15 C18:3 $_{\text {Nutritional value }}$ & 5.2 \\
NE ${ }_{\mathrm{L}}, \mathrm{kcal} / \mathrm{kg}$ of DM & 1,640 \\
PDIE, ${ }^{2}$ g/kg of DM & 90 \\
PDIN, g/kg of DM & 103 \\
\hline
\end{tabular}

${ }^{1}$ The chemical composition values do not include the lipid-encapsulated conjugated linoleic acid supplement (lipid content of $65 \%$ and FA composition of $15 \%$ trans-10,cis-12 C18:2, 15\% cis-9,trans-11 C18:2, $9 \% 16: 0 ; 42 \% 18: 0,12 \%$ cis-9 C18:1, $1 \%$ cis- 9 , cis- $12 \mathrm{C} 18: 2$, and $6 \%$ unknown FA) or Ca salts of palm oil [control (CTL)] supplement (lipid content of $90 \%$ with $50 \%$ C16:0, 35\% C18:1 cis-9, $10 \%$ cis-9, cis-12 C18:2, and 5\% unknown FA).

${ }^{2} \mathrm{PDIN}$ and PDIE $=$ digestible protein in the intestine when rumen fermentable $\mathrm{N}$ supply or rumen energy supply are limiting, respectively (INRA, 2007). 
measured DMI, milk yield, and fat yield. Each block was randomly allocated to CTL $\left(5.6 \mathrm{kcal}\right.$ of $\left.\mathrm{NE}_{\mathrm{L}} / \mathrm{g}\right)$ or CLA treatment (Lutrell; BASF Animal Nutrition, Château-Gontier, France; 4.9 kcal of $\mathrm{NE}_{\mathrm{L}} / \mathrm{g}$ ) during wk 4 to 8. Lipid supplements (CTL or CLA) distributed as 15 and $30 \mathrm{~g}$ in the morning and afternoon feeding (in the same proportion as the feed distributed) were topdressed on the diet and thoroughly hand mixed; CLA treatment provided $4.5 \mathrm{~g}$ of cis-9,trans-11 C18:2/d and $4.5 \mathrm{~g}$ of trans-10,cis-12 C18:2/d. Within each block, one goat was fed a restricted FL to cover $100 \%$ of its calculated energy requirements (INRA, 2007), whereas the other was fed $85 \%$ of the DMI of the first goat. This resulted in 4 groups of 6 goats according to a $2 \times 2$ factorial design, with the FL (100 vs. $85 \%$ of energy requirements: FL100 vs. FL85) and lipid supplementation (CTL vs. CLA) as factors. The same strategy was applied until the end of the trial, allowing the necessary amount of DM offered to be calculated for each week of the experiment.

\section{Experimental Measurements and Sampling}

From wk 2 onwards, feed intake was recorded daily. Three diet samples were collected at wk 3,4 , and 7 for feed composition analyses and total FA determination. Goats were weighed once per week at the same time in the middle of the day. From wk 1 to 8, 2 milk samples of $30 \mathrm{~mL}$ (one at the evening milking and one at the following morning milking) were individually collected each week, a preservative (bronopol; Grosseron SA, Saint-Herblain, France) was added, and the samples were stored at $4^{\circ} \mathrm{C}$ until milk composition analysis (total protein, fat, lactose, and urea) by infrared spectrophotometry in a Milk Recording Organisation laboratory (Syndicat Interdépartemental de l'Élevage, Le Mée, France). During wk 3, 5, and 7, 2 additional milk samples of $30 \mathrm{~mL}$ (one at the evening milking and one at the following morning milking) were individually collected without preservative, and stored at $-18^{\circ} \mathrm{C}$ for milk FA composition.

Blood samples were collected weekly by jugular venipuncture into heparin vials in the morning $(0700 \mathrm{~h})$, before the milking and before the distribution of the diet. The blood samples $(10 \mathrm{~mL})$ were centrifuged at $1,780 \times g$ for $10 \mathrm{~min}$ at $4^{\circ} \mathrm{C}$ immediately after collection. Plasma was removed and stored at $-18^{\circ} \mathrm{C}$ until glucose, NEFA, BHBA, urea, and insulin analysis.

\section{Laboratory Analysis}

Feed samples were dried in a forced-air oven at $90^{\circ} \mathrm{C}$ for $24 \mathrm{~h}$ to determine DM content, and then ground and stored at room temperature until determination of their contents of OM, NDF, and ADF (Van Soest et al., 1991) and starch (Gluco-sequant Glucose/HK; Roche/ Hitachi Diagnostics GmbH, Mannheim, Germany). Dry matter, ash, and enzymatic starch content in feed were determined following International Organization for Standardization (ISO) standards: ISO (1999; ISO 6496), ISO (2002; ISO 5984), and ISO (2004; ISO 15914), respectively. The 2 other feed samples were immediately stored at $-20^{\circ} \mathrm{C}$, to be subsequently lyophilized and ground for FA analysis according to Folch et al. (1957). Milk fat was extracted twice with ethanol/12 $\mathrm{N} \mathrm{HCl}$ /hexane and tricosanoic acid (C23:0; $0.5 \mathrm{mg} / \mathrm{mL}$ ) was added as internal standard to the solution. Then, FA were methylated at room temperature with a methanolic boron trifluoride solution (14\%, wt/ vol). Methyl esters of FA were finally recovered in hexane. Methyl esters from milk or feed samples were then injected with an autosampler into a Varian CP 3800 gas chromatograph equipped with a flame ionization detector (Varian SA, Les Ulis, France) on a CP-Sil 88 column $(100 \mathrm{~m} \times 0.25 \mathrm{~mm}$ i.d. fused silica capillary column; Interchim, Montluçon, France). The carrier gas was ultra-pure helium with a flow of $1 \mathrm{~mL} / \mathrm{min}$ (pressure of $275.8 \mathrm{kPa}$ ). The injector and detector temperatures were maintained at $250^{\circ} \mathrm{C}$. The split ratio in the injector was 20:1. The initial oven temperature was $50^{\circ} \mathrm{C}$ (for $1 \mathrm{~min}$ ), which was increased at $10^{\circ} \mathrm{C} / \mathrm{min}$ to $170^{\circ} \mathrm{C}$ (held for $78 \mathrm{~min}$ ) and then increased at $5^{\circ} \mathrm{C} / \mathrm{min}$ to $220^{\circ} \mathrm{C}$ (held for $15 \mathrm{~min}$ ). Individual FA were identified by comparison of retention time to those of pure standards (Supelco Inc., Bellefonte, PA). Identification of trans C18:1 isomer peaks other than trans-9 C18:1 and trans-11 C18:1 (commercially available) was done as described by LeDoux et al. (2002). Milk FA yields were calculated according to the method of Glasser et al. (2007).

For plasma glucose, NEFA, BHBA, and urea analyses, an autoanalyzer (Cobas-Mira; Roche/Hitachi, Diagnostics $\mathrm{GmbH}$ ) was used with kits [Gluco-sequant glucose/HK (Roche/Hitachi Diagnostics GmbH); NEFA-HR(2) (Wako Chemicals GmbH, Neuss, Germany)]. $\beta$-Hydroxybutyrate was analyzed by the method of Barnouin et al. (1986). Insulin was analyzed with an ELISA kit (10-1202-01; Mercodia AB, Uppsala, Sweden). Urea was analyzed with a quantification kit (Urea Kinetic UV test, 11489321 216; Roche/Hitachi Diagnostics GmbH).

\section{Statistical Analysis}

Weekly mean values of DMI, BW, milk yield and composition, and plasma concentrations of NEFA, glucose, insulin, and BHBA data were analyzed using a factorial design with PROC MIXED of SAS (SAS 
Institute Inc., Cary, NC) for repeated measures according to the following statistical model:

$$
\begin{aligned}
\mathrm{Y}_{\mathrm{ijkl}}= & \mu+\mathrm{A}_{\mathrm{i}}+\mathrm{B}_{\mathrm{j}}+\mathrm{C}_{\mathrm{k}}+\mathrm{AB}_{\mathrm{ij}}+\mathrm{AC}_{\mathrm{ik}} \\
& +\mathrm{D}_{\mathrm{l}}+\mathrm{BC}_{\mathrm{jk}}+\mathrm{Cov}_{\mathrm{l}}+\varepsilon_{\mathrm{ijk} \mathrm{k}},
\end{aligned}
$$

where $\mathrm{Y}_{\mathrm{ijkl}}$ is the response variable, $\mu$ is the overall mean, $\mathrm{A}_{\mathrm{i}}$ is the fixed effect of CLA treatment (CTL vs. CLA), $B_{j}$ is the fixed effect of FL (100 vs. $85 \%$ of energy requirements), $\mathrm{C}_{k}$ is the fixed effect of time (5 $\mathrm{wk}), \mathrm{AB}_{\mathrm{ij}}$ is the interaction between the CLA treatment and $\mathrm{FL}, \mathrm{AC}_{\mathrm{ik}}$ is the interaction between the CLA treatment and time, $\mathrm{BC}_{\mathrm{jk}}$ is the interaction between $\mathrm{FL}$ and time, $\mathrm{Cov}_{1}$ is a covariate measured at the end of wk 3 , and $\varepsilon_{\mathrm{ijkl}}$ is the residual error. Goat was considered as a random effect $\left(D_{1}\right)$. A first-order autoregressive [AR (1)] covariance structure was used for repeated measures. The same model was used to evaluate the effect of the different factors on milk FA secretion and profile measured during wk 3,5 , and 7 , with wk 3 values used as a covariate. Least squares means are reported and treatment effects were declared significant at $P<0.05$.

\section{RESULTS}

\section{Animal Performance}

Temporal changes in DMI, milk yield, and milk fat and milk protein yields during the trial are presented in Figure 1. During the whole trial, DMI, milk yield, and fat and protein yields decreased. Compared with the FL100 goats (Table 2), the FL85 goats had lower DMI $(-13 \%)$ and lower calculated NEB $(-475 \mathrm{kcal} / \mathrm{d})$ and protein digestible in the intestine (PDI) balance $(-15.6 \mathrm{~g} / \mathrm{d})$. The changes in BW were -0.17 and -0.14 $\mathrm{kg} / \mathrm{d}(\mathrm{SEM}=0.03 ; P<0.01)$ for the FL85 and FL100 goats, respectively. Body weight; milk yield; milk fat, protein, and lactose yields; milk energy output; and fat, protein, lactose, and urea contents in milk were not affected by FL.

Compared with goats fed the CTL supplement, those fed CLA had lower fat yield $(-19 \%)$, lower milk fat content $(-17 \%)$, and higher milk energy output $(+340$ kcal). The DMI, milk protein and lactose yields, and protein, lactose, and urea contents in milk were unaffected by CLA. The changes in BW were -0.18 and
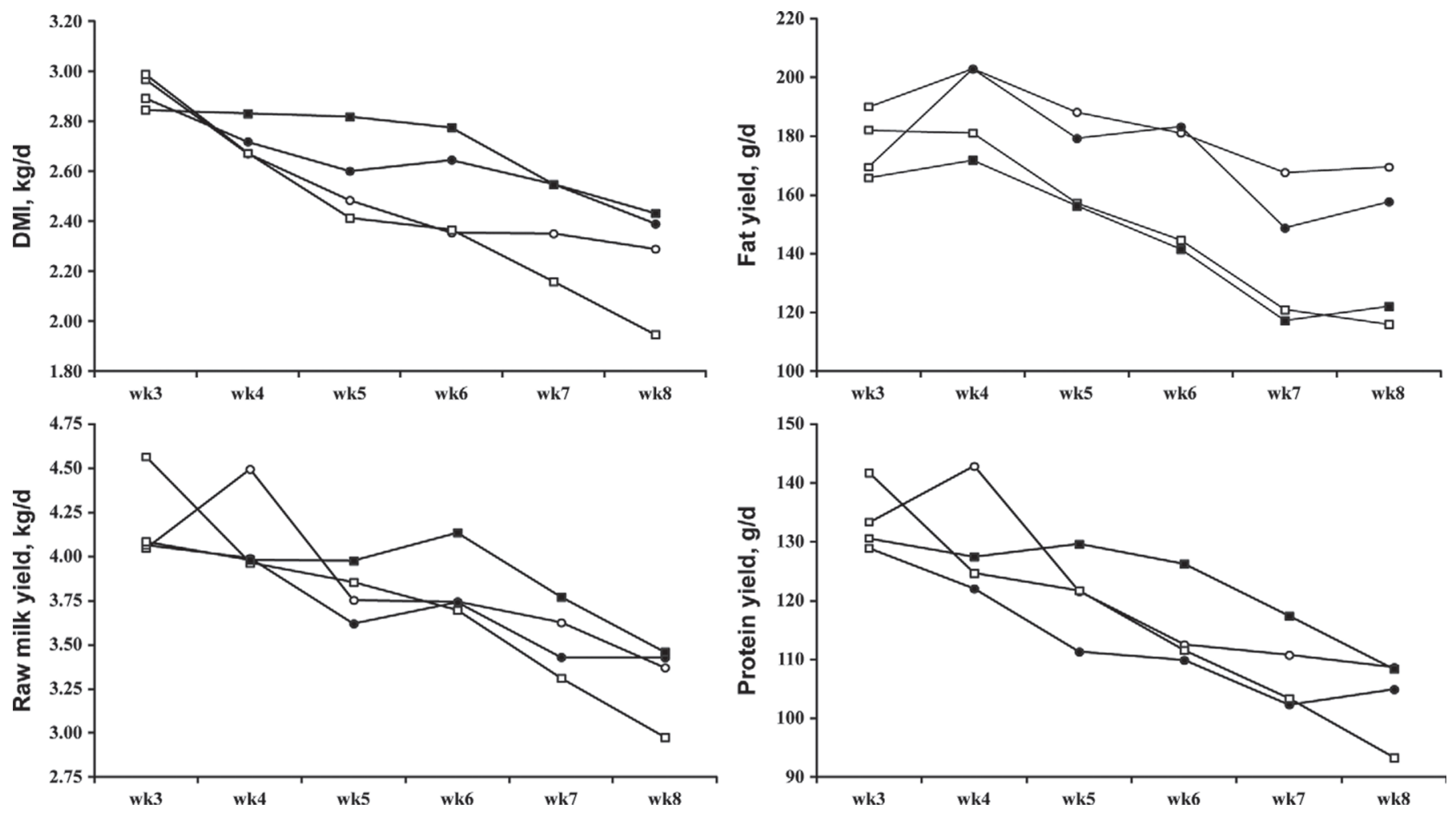

Figure 1. Temporal pattern of DMI, milk yield, fat yield, and protein yield in goats fed $45 \mathrm{~g}$ of Ca salts of palm oil/d [control (CTL); $\bigcirc$, - $]$ or $45 \mathrm{~g}$ of CLA/d (4.5 g of trans-10,cis-12 C18:2 + 4.5 g of cis-9,trans-11 C18:2; $\square$, 口) at 2 feeding levels [FL; $100(\bullet, \mathbf{0})$ vs. 85\% (○, $\square)$ of energy requirements]. Experimental treatments were introduced at the end of wk 3. Values presented are LSM, with data measured during wk 3 used as covariates. The SEM for DMI, milk yield, fat yield, and protein yield were $0.078 \mathrm{~kg} / \mathrm{d}, 0.11 \mathrm{~kg} / \mathrm{d}, 4.38 \mathrm{~g} / \mathrm{d}$, and $3.00 \mathrm{~g} / \mathrm{d}$, respectively. 
GHAZAL ET AL.

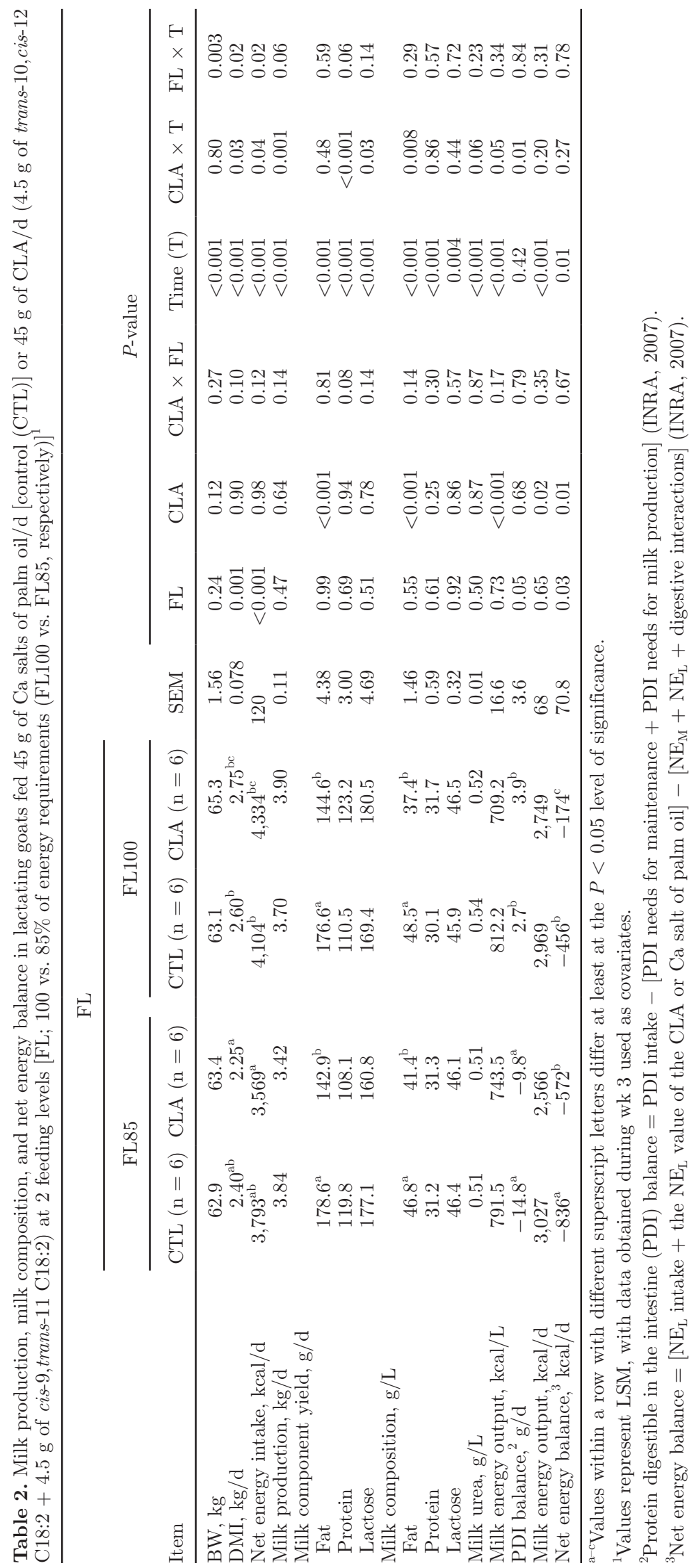


$-0.13 \mathrm{~kg} / \mathrm{d}(\mathrm{SEM}=0.03 ; P<0.01)$ for the goats fed the CTL supplement and the CLA supplement, respectively. Although exhibiting negative calculated NEB, the goats fed CLA had higher NEB $(+375 \mathrm{kcal} / \mathrm{d})$ than those fed the CTL supplement. Goats fed the FL100 $\times$ CLA diet tended to have the highest DMI (interaction of FL $\times$ CLA: $P<0.10)$ and the highest protein yield (interaction of FL $\times$ CLA: $P<0.08$ ). The interaction between CLA and FL was not significant for any other variables.

\section{Milk FA Secretion and Profile}

Secretion of $<16-C$ FA, the sum C16:0 + cis-9 C16:1, and $>16-\mathrm{C} \mathrm{FA}$ in milk was not affected by FL (Figure 2). Compared with FL100 goats, the FL85 goats had higher proportions of the sum of trans-C18:1, total PUFA, and total C16. When the FA were considered individually (Appendix Table A1), FL85 goats had lower proportions of $\mathrm{C} 18: 0, \mathrm{C} 20: 0$, and anteiso C15:0 and higher proportions of trans-6,-7,-8 C18:1, trans-9 C18:1, trans-11 C18:1, and cis-9,trans-11 C18:2 in milk. Desaturation ratios for C14:0, C16:0, and C18:0 were not affected by FL.
Compared with goats fed the CTL supplement (Figure 2), those fed CLA had lower milk secretion of $<16-\mathrm{C} \mathrm{FA}$ (308 vs. $248 \mathrm{mmol} / \mathrm{d}$ for CTL and CLA, respectively), the sum of C16:0 + cis-9 C16:1 (189 vs. $146 \mathrm{mmol} / \mathrm{d}$ ), and >16-C FA (176 vs. $155 \mathrm{mmol} / \mathrm{d}$ ). No interaction was observed between CLA and FL on milk secretion of any group of FA. Compared with goats fed the CTL supplement, those fed CLA had higher proportions of total iso + anteiso $\mathrm{FA}$ and of $>\mathrm{C} 16 \mathrm{FA}$ (Table 3), and they tended to have higher proportions of total saturated FA and total trans-FA $(P<0.08$ and $P<0.09$, respectively). Conversely, goats fed the CLA supplement had lower proportions of total 16-C FA and total cis-C18:1. The interaction between CLA and FL was not significant on the proportions of the different groups of FA in milk. All desaturation ratios were dramatically reduced by the CLA supplement, with 39 , 21 , and $50 \%$ decreases for the ratios of cis-9 C14:1/ C14:0, cis-9 C16:1/C16:0, and cis-9 C18:1/C18:0, respectively. When the FA were considered individually (Appendix Table A1), goats fed the CLA supplement had lower proportions of SFA with 8 to 13 carbons, C16:0, and cis-9 C18:1 FA, and higher proportions of C4:0, C14:0, C15:0, C18:0, C20:0, all iso FA, and

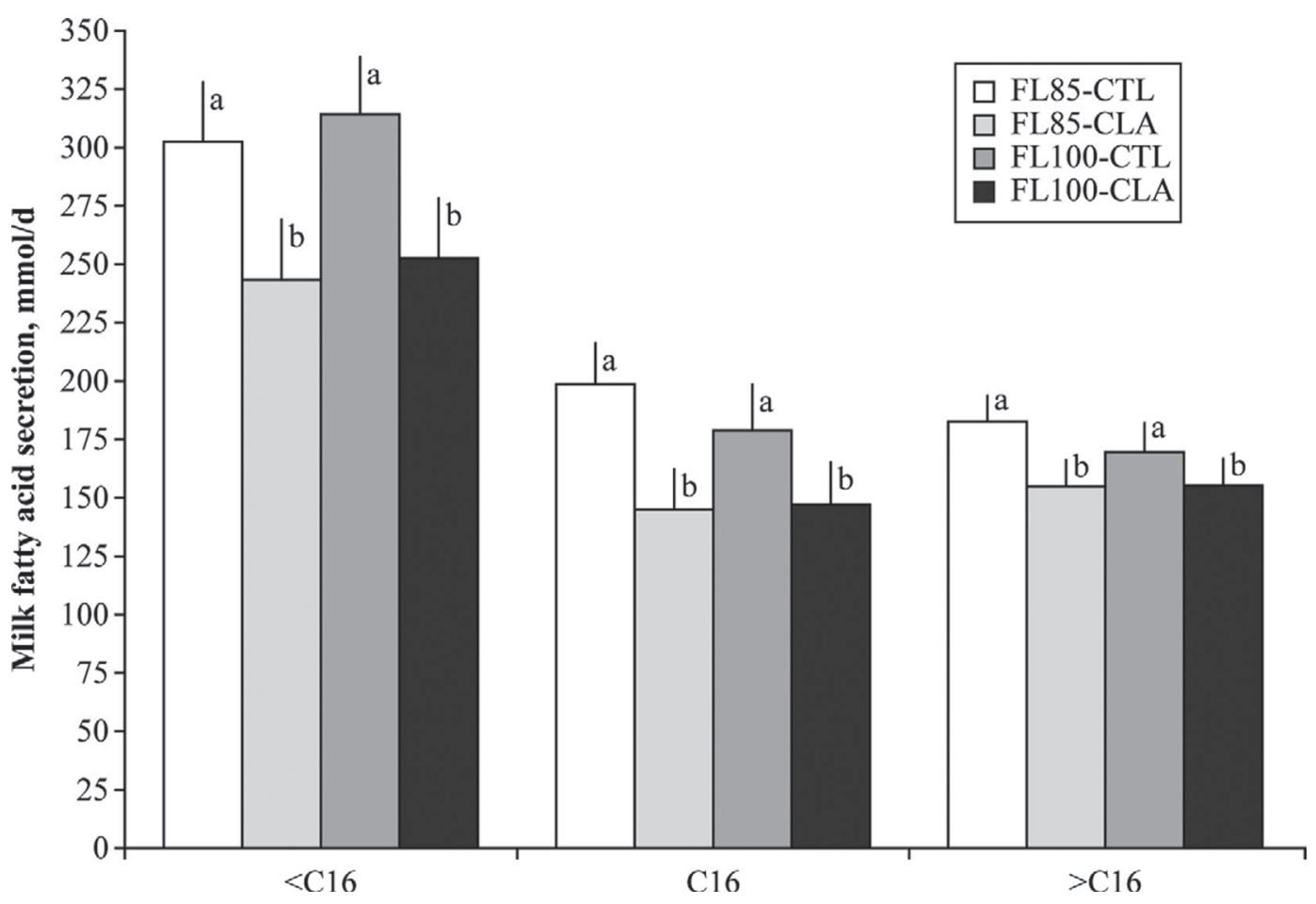

Figure 2. Milk FA secretion (mmol/d) in lactating goats fed $45 \mathrm{~g}$ of Ca salts of palm oil/d [control (CTL)] or $45 \mathrm{~g}$ of CLA/d (4.5 g of trans10,cis-12 C18:2 + $4.5 \mathrm{~g}$ of cis-9,trans-11 C18:2) at 2 feeding levels [FL; 100 vs. 85\% of energy requirements (FL100 vs. FL85, respectively)]. Fatty acids are categorized according to metabolic origin: $<16$-C FA $(<$ C16) synthesized de novo, C16:0 + C16:1 (C16), and $>16-\mathrm{C}$ FA $(>$ C16) taken up from circulating plasma lipids. Values presented are LSM $( \pm \mathrm{SE})$, with data measured during wk 3 used as covariates. Bars with different letters ( $\mathrm{a}$ and $\mathrm{b}$ ) differ at least at the $P<0.002$ level of significance. 
trans-11, trans-13,-14, and trans-16 isomers of C18:1. In goats fed CLA, the proportion of trans-10,cis-12 C8:2 and its daily secretion in milk fat $(0.27$ and 0.17 $\mathrm{mg} / \mathrm{d}$ for FL85 and FL100, respectively; SEM $=0.02$ $\mathrm{mg} / \mathrm{d} ; P<0.004)$ were higher in FL85 than in FL100 goats. Consequently, the apparent efficiency of transfer of trans-10,cis-12 C18:2 CLA from dietary supplement to milk fat $\{100 \times[$ trans-10, cis-12 C18:2 output in milk $(\mathrm{g} / \mathrm{d})] /[$ trans-10,cis-12 C18:2 intake $(\mathrm{g} / \mathrm{d})]\}$ was 6.1 and $3.75 \%$ for FL85 and FL100, respectively $(\mathrm{SEM}=0.44$; $P<0.004)$. No other interactions between CLA and FL were observed for individual milk FA (Appendix Table A1).

\section{Plasma Metabolite Concentrations}

Compared with FL100 goats FL85 goats had a lower BHBA concentration $(P<0.001$; Table 4$)$ and numerically lower glucose and insulin concentrations $(P<$ 0.10). Compared with goats fed the CTL supplement, those fed CLA tended to have lower NEFA and BHBA ( $P<0.09$ and $P<0.08$, respectively), and higher glucose $(P<0.06)$ concentrations. The interactions between CLA and FL on the different plasma metabolite concentrations were not significant.

\section{DISCUSSION}

The objective of this trial was to study the effect of lipid-encapsulated trans-10, cis-12 C18:2 on milk performance of pair-fed lactating goats fed either to cover their energy requirements or to restrict energy intake, to test if the FL may affect response to trans-10, cis-12 C18:2. Feed restriction was arbitrarily set to an average $85 \%$ of the daily intake needed to cover $100 \%$ of calculated energy requirements for maintenance and milk production, to compare with similar dietary restrictions previously reported in cows (de Veth et al., 2006) and in ewes (Sinclair et al., 2007; Weerasinghe et al., 2012). In those studies, feed restriction was either not compared with groups fed at a high FL (de Veth et al., 2006; Weerasinghe et al., 2012) or compared with a fixed high FL exceeding energy requirements for lactation and maintenance (Sinclair et al., 2007), which may have affected the animal response to CLA. In our study, feed restriction (FL85) was achieved by pair-feeding goats, which allows a direct evaluation of interaction between trans-10,cis-12 C18:2 and feed level on milk-production characteristics. We obtained a mean of $13 \%$ lower DMI for feed-restricted goats compared with goats fed FL100. However, on average, during the whole trial, the goats fed the restricted level had only $8 \%$ lower DMI in CTL groups and $20 \%$ lower DMI in CLA groups (interaction of CLA $\times$ FL: $P<$
$0.10)$. This was due to an increased rate of refusals in group CTL $\times$ FL100 during the last 2 wk of the trial, with no obvious explanation. Consequently, goats fed FL100 in the CTL group were not strictly at a zero $\mathrm{NE}_{\mathrm{L}}$ balance $\left(-174 \mathrm{kcal}\right.$ of $\left.\mathrm{NE}_{\mathrm{L}} / \mathrm{d}\right)$. However, this does not constitute a major drawback with respect to our objectives. In our trial, the FL85 goats had similar milk yield to the FL100 goats, as previously reported in ewes (Sinclair et al., 2007), probably due to higher body reserves mobilization to sustain milk production at this stage of lactation.

The apparent transfer efficiency (ATE) of trans10,cis-12 C18:2 in lipid-encapsulated CLA supplement similar to that used in the present study ranges between 1.5 to $6 \%$ in the ewe (Weerasinghe et al., 2012) and in the cow (Pappritz et al., 2011). In our study, the ATE of trans-10,cis-12 C18:2 from the diet to milk was lower in FL100 goats than in FL85 goats, but, on average, higher than that observed in goats fed ad libitum (Ghazal et al., 2012) within experimental conditions very close to those of the current study (when considering FL100 goats). This difference in ATE of trans-10,cis-12 C18:2 is not due to ruminal production of trans-10, cis-12 C18:2, because we did not detect any trans-10, cis-12 C18:2 at any time in the milk of CTL goats in the present experiment, or in that of Ghazal et al. (2012). Instead, differences in ATE seem to be related to the level of DMI, as FL expressed relative to $\mathrm{BW}$ was $5.0,4.2$, and $3.5 \%$ with $\mathrm{ATE}=2,3.75$, and $6.1 \%$ respectively, for goats fed ad libitum in the study of Ghazal et al. (2012), for FL100 goats, and for FL85 goats, respectively. This is rather surprising because it was expected that a higher FL would increase ruminal turnover, thus decreasing ruminal biohydrogenation of protected CLA. However, our data are in line with decreased duodenal flows of cis-9, cis-12 C18:2 and C18:1 cis-FA observed with high FL (Qiu et al., 2004), which indicates increased biohydrogenation with high FL (Glasser et al., 2008). Changes in DMI could have modified environmental conditions within the rumen that may have affected microbial population or activity, or both (Lourenço et al., 2010). Moreover, it cannot be ruled out that changes in DMI may have also altered digestion and absorption of trans-10, cis-12 C18:2. High variability of apparent postruminal digestibility of trans-10, cis-12 C18:2 have been reported in cows Pappritz et al. (2011), which may explain changes in ATE between experiments.

\section{Effect of CLA on Milk and Protein Yields in FL85 and FL100 Goats}

We hypothesized that trans-10,cis-12 C18:2 may increase milk production or protein yield in dairy goats 


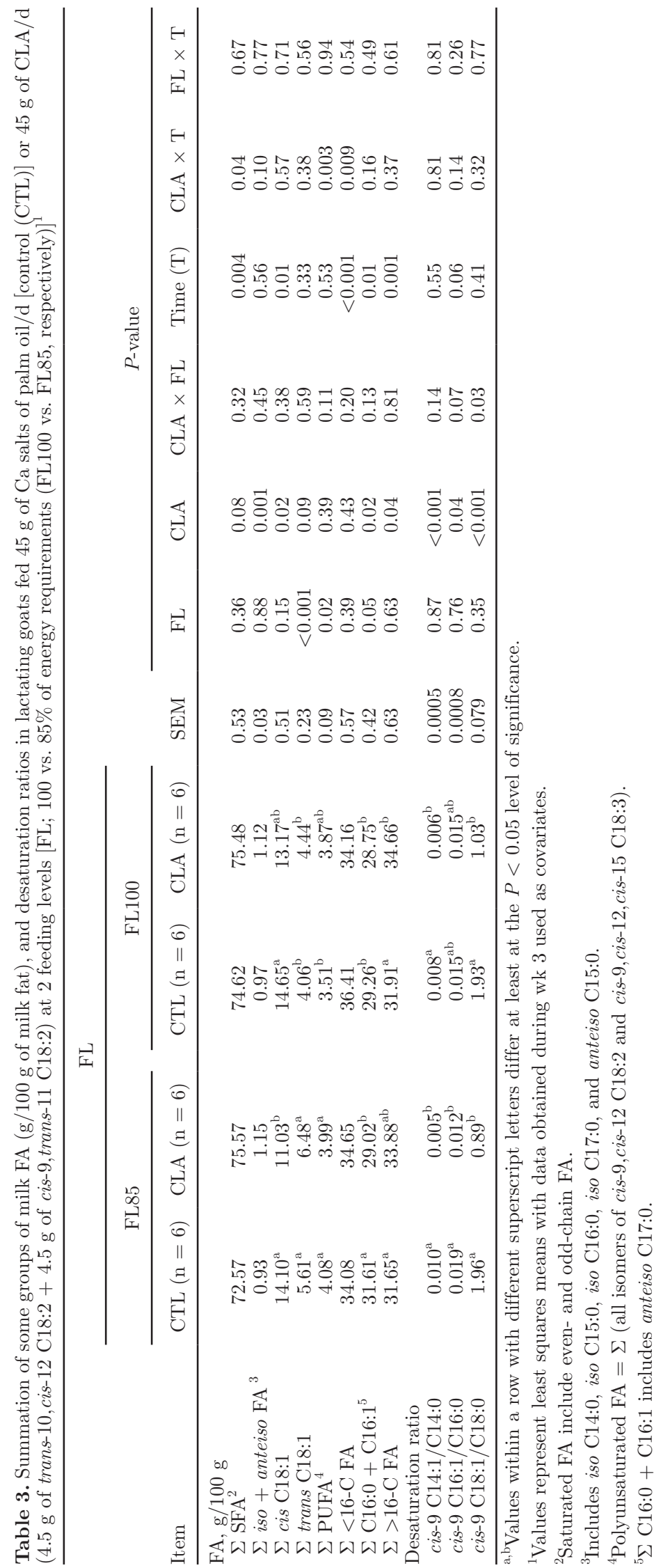




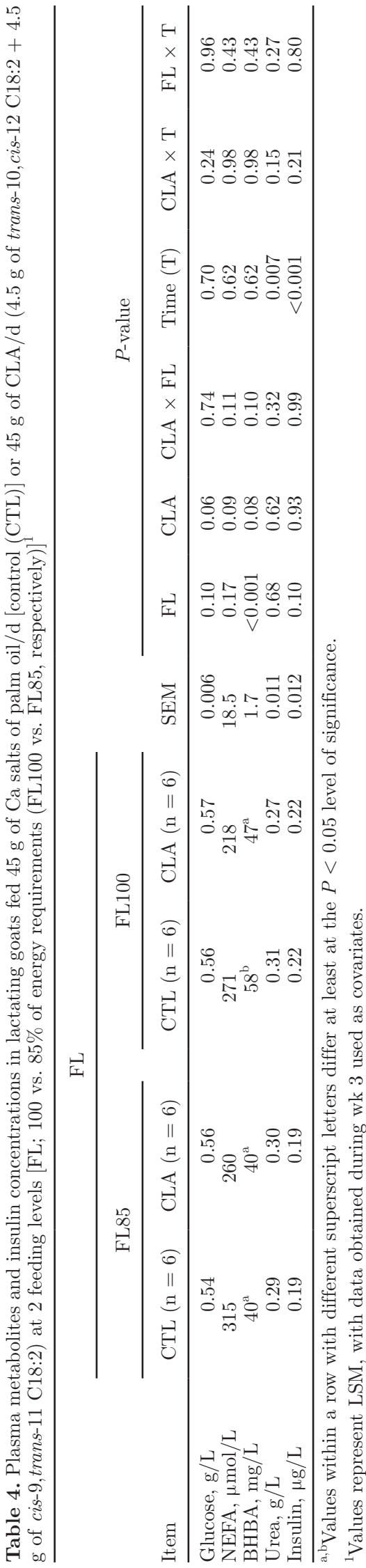

even in the case of limited energy intake. Indeed, reduction in energy needed for milk fat synthesis after trans10,cis-12 C18:2 supplementation may help partitioning of available energy toward milk production or milk protein synthesis. In our trial, the reduction in milk fat yield due to trans-10,cis-12 C18:2 supplementation (see below) was equivalent to 340 and $300 \mathrm{kcal}$ of $\mathrm{NE}_{\mathrm{L}} / \mathrm{d}$ for FL85 and FL100 goats, respectively, which represented $20 \%$ of energy being spared from milk fat synthesis, independent of the FL group. A similar reduction in milk energy output due to lower fat synthesis in the mammary gland after trans-10,cis-12 C18:2 supplementation was observed in ewes fed at a high $(2.1 \mathrm{~kg}$ of $\mathrm{DMI} / \mathrm{d}$ ) versus a low $(1.7 \mathrm{~kg}$ of DMI /d) FL (Sinclair et al., 2007), or in ewes and cows fed $80 \%$ of their ME requirements (de Veth et al. 2006; Weerasinghe et al., 2012). A higher reduction in milk energy output was observed in dairy cows fed ad libitum versus restricted pasture (Kay et al., 2006), probably because of the high dosage of trans-10,cis-12 C18:2 (9 g/d), and because of its abomasal infusion, which was reflected by the high trans-10, cis-12 C18:2 content in milk (0.65\% of total milk FA).

Increases in milk yield or protein yield with CLA have sometimes been observed in ewes (Lock et al., 2008; Sinclair et al., 2010) and in cows (Perfield et al., 2004) fed ad libitum, but the responses are generally inconsistent, at least in cows (reviewed by Harvatine et al., 2009). Conversely, when energy availability was limited, as in early lactation (Castañeda-Gutiérrez et al., 2007), at pasture feeding (Kay et al., 2006), or during dietary energy restriction (de Veth et al., 2006; Weerasinghe et al., 2012), milk yield and protein yield were increased, although this response could be of low amplitude (Sinclair et al., 2007). Despite the lower milk energy output associated with the reduction in milk fat synthesis in the present study, milk yield and protein yield were not affected by trans-10, cis-12 C18:2. This was observed independently of the FL group, although FL100 goats exhibited numerical increases in protein yield $(+11 \%$; interaction of CLA $\times$ FL: $P<0.08)$ and lactose yield $(+7 \%)$ over the CTL goats. In FL100 goats, it can be calculated that approximately $36 \%$ of the energy spared due to the lower milk fat secretion after trans-10, cis-12 C18:2 may have been used for lactose and protein secretion, with the extra $+200 \mathrm{kcal}$ of $\mathrm{NE}_{\mathrm{L}}$ spared being diverted away from milk. Conversely, in FL85 goats, none of the energy spared by the lower milk fat yield due to trans-10,cis-12 C18:2 was partitioned toward lactose or protein synthesis, which was, if anything, numerically reduced: in these conditions, approximately $460 \mathrm{kcal} / \mathrm{d}$ from milk energy output was spared in the goats fed trans-10,cis-12 C18:2. This suggests that response to the energy-sparing effect of CLA 
may be affected by nutritional status and primarily by the magnitude of negative energy balance. In dairy cows experiencing negative $\mathrm{NE}_{\mathrm{L}}$ balance, reduction in milk fat yield would allow available energy to be partitioned toward milk or protein, reflecting the priority of nutrient utilization (Bauman and Currie, 1980). However, despite being in negative $\mathrm{NE}_{\mathrm{L}}$ balance, FL85 goats in the present trial did not increase their milk and protein yields after trans-10,cis-12 supplementation. This is probably related to the fact that these goats (FL85) experienced not only a shortage in energy but also a shortage in protein, as indicated by their negative PDI balance, whereas FL100 goats had positive PDI balance and those supplemented with trans-10,cis-12 had higher protein yield. Increases in milk and protein yields with CLA supplementation were observed at pasture (Kay et al., 2006), a situation where energy, but not CP, may be the limiting factor of the response, or during energy restriction with excess $\mathrm{CP}$, or moderately deficient $\mathrm{CP}$ (de Veth et al., 2006; Weerasinghe et al., 2012). Amino acids are implicated in different metabolic processes, such as neoglucogenesis, which provide glucose for milk synthesis (Aschenbach et al., 2010), and as precursors of protein synthesis in mammary gland (Lapierre et al., 2012). Moreover, it cannot be ruled out that FL85 goats may have reduced uptake of AA by the mammary gland as a consequence of lower plasma insulin concentration, which has been demonstrated as a key hormone in relation to mammary uptake of AA and protein metabolism in the mammary gland (Bequette et al., 2001). Globally, FL85 goats did not to increase milk and protein yield probably because of the simultaneous shortage in energy and protein supply.

Reduction in milk energy output after trans-10, cis-12 supplementation was reflected in a less negative calculated $\mathrm{NE}_{\mathrm{L}}$ balance and possibly associated with lower mobilization of body reserves, as indicated by the lower NEFA plasma concentration in both FL. This is in line with the reduced mobilization of adipose tissue and lipid body mass in early-lactation cows fed trans10,cis-12 C18:2 (von Soosten et al., 2011, 2012) but contrast with those obtained in dairy ewes that showed no change in carcass lipid content after trans-10, cis-12 C18:2 supplementation (Sinclair et al., 2010).

\section{Effect of CLA on Milk Fat Secretion and Profile in FL85 and FL100 Goats}

Despite a slightly higher trans-10,cis-12 C18:2 concentration in the milk fat of FL100 goats in the current study than previously reported (Ghazal et al., 2012), the reduction in milk fat secretion $(-18 \%)$ and milk fat content $(-23 \%)$ were similar. In dairy goats, a reduction between 10 and $20 \%$ of milk fat secretion is gen- erally obtained from a range of trans-10,cis-12 C18:2 concentrations in milk fat between 0.10 and $0.25 \%$ of total milk fat, which generally corresponds to a daily oral dose of between 3 and $7 \mathrm{~g}$ of encapsulated trans10,cis-12 C18:2 (Lock et al., 2008; Shingfield et al., 2009; Ghazal et al., 2012). In our trial, this reduction in milk fat secretion in FL100 goats was mainly associated with the simultaneous decrease in the mammary secretions of $<16-\mathrm{C} \mathrm{FA}(-16 \%)$ and C16 FA $(-26 \%)$, which are in the same range as previously reported in goats fed ad libitum (Lock et al., 2008; Shingfield et al., 2009; Ghazal et al., 2012). Among $<16-\mathrm{C}$ FA, only those with 8 to $13 \mathrm{C}$ were reduced, whereas all $\mathrm{FA}$ arising from lipogenesis are affected in cows and ewes (Bauman et al., 2011). This partly reflects the lower sensitivity of goats to the antilipogenic effect of trans-10,cis-12 C18:2 (Shingfield et al., 2010). In dairy cows and ewes, the decrease in de novo mammary lipogenesis has been shown to reflect a trans-10,cis-12 C18:2 coordinated downregulation of mRNA expression or of activity of lipogenic enzymes in the mammary gland (Baumgard et al., 2002; Gervais et al., 2009; Hussein et al., 2013), implicating a role for sterol response element-binding protein 1 and spot 14 at the cellular signaling level (Peterson et al., 2004; Harvatine and Bauman, 2006).

In FL100 goats, the decrease in $>16$-C FA secretion $(-15 \%)$ after trans-10,cis-12 C18:2 supplementation had a similar amplitude to that of $<16-\mathrm{C}$ FA. This decrease in $>16-\mathrm{C}$ FA secretion reflects a reduction in mammary mRNA abundance of lipoprotein lipase (LPL; Hussein et al., 2013), the mammary enzyme that is responsible for the uptake of triacylglycerol arising from blood via digestive chylomicrons or hepatic very low-density lipoproteins. In cows and ewes, the decrease in fat yield after trans-10,cis-12 C18:2 supplementation was related to a greater decrease in FA arising from de novo lipogenesis than that from FA taken up by the mammary LPL (Bauman et al., 2008; Hussein et al., 2013). Our data are in accordance with results previously reported in goats in early lactation (Ghazal et al., 2012) and in goats with higher milk fat concentration of trans-10, cis-12 C18:2 during late lactation (Baldin et al., 2014), but in contrast to other results in goats during mid to late lactation (Lock et al., 2008; Shingfield et al., 2009). These discrepancies may be related to the initial level of $>16-\mathrm{C}$ FA secretion or to the stage of lactation as previously suggested (Ghazal et al., 2012). Indeed, milk FA secretion and LPL activities are higher in early than in mid to late lactation (Bernard et al., 2008), and they may consequently be more sensitive to the inhibiting effect of trans-10,cis-12 C18:2 on the uptake of long-chain FA. Taken together, these results indicate a significant effect of trans-10,cis-12 C18:2 on LPL activities that may differ according to species, 
stage of lactation, and possibly to the dosage of trans10, cis-12 C18:2. Among >16-C FA, the proportion of C18:0 was dramatically increased at the expense of cis-9 C18:1 after trans-10,cis-12 C18:2, which indicates a decrease either in the activity of mammary stearoylCoA desaturase (SCD1; Bernard et al., 2008) or in mRNA abundance of the SCD1 gene (Hussein et al., 2013). Generally, a reduced SCD1 activity has been observed with a high dosage of trans-10,cis-12 C18:2 in cows (Peterson et al., 2004), ewes (Sinclair et al., 2010), and goats (de Andrade and Schmidely, 2011) but not with a low dosage (Maxin et al., 2011).

The interaction between trans-10,cis-12 C18:2 supplementation and FL on milk fat yield, milk secretion of any group of FA, or the proportions of most FA in milk fat was not significant. This is in agreement with most of trials reporting no interaction between trans10,cis-12 C18:2 and either FL (Kay et al., 2006; Sinclair et al., 2007) or energy restriction (de Veth et al., 2006; Weerasinghe et al., 2012) in ewes and cows exhibiting zero or positive NEB. Because NEB was negative in the present study, it suggests that nutrients of either dietary origin or arising from adipose tissues mobilization do not interact with trans-10,cis-12 treatment to alter milk fat secretion by the mammary gland. This is in agreement with the results reporting additive effects of acetate or propionate availability and trans-10, cis-12 C18:2 on mammary FA synthesis, and a greater effect of trans-10,cis-12 to alter milk fat secretion than nutrient availability (Maxin et al., 2010, 2011).

\section{CONCLUSIONS}

Dietary supplementation of lipid-encapsulated CLA, containing trans-10, cis-12 C18:2, to dairy goats at high versus low levels of feeding decreased milk fat yield and milk fat content, independent of the level of feeding. The energy spared by the milk fat reduction was not partitioned toward milk lactose or protein in goats at the low FL, but instead lowered the mobilization of body tissues. In goats at the high FL, energy spared tended to be partitioned toward milk protein yield, and simultaneously to the prevention of excessive lipid mobilization.

\section{ACKNOWLEDGMENTS}

We are grateful to J. Tessier and his team for carrying out the experiment on goats. We thank O. Dhumez, F. Ternois, and L. Péricard (all from INRA, UMR791 Modélisation Systémique Appliquée aux Ruminants, Paris and Thiverval-Grignon, France) for the analysis of the samples.

\section{REFERENCES}

Aschenbach, J. R., N. B. Kristensen, S. S. Donkin, H. M. Hammon, and G. B. Penne. 2010. Gluconeogenesis in dairy cows: The secret of making sweet milk from sour dough. IUBMB Life 62:869-877.

Baldin, M., R. Dresch, J. Souza, D. Fernandes, M. A. S. Gama, K. J. Harvatine, and D. E. Oliveira. 2014. CLA induced milk fat depression reduced dry matter intake and improved energy balance in dairy goats. Small Rumin. Res. 116:44-50.

Barnouin, J., N. el Idilbi, Y. Chilliard, J. P. Chacornac, and R. Lefaivre. 1986. Automated micro-determination of bovine plasma 3-hydroxybutyrate without deproteinization. Ann. Rech. Vet. 17:129-139.

Bauman, D. E., and W. B. Currie. 1980. Partitioning of nutrients during pregnancy and lactation: A review of mechanisms involving homeostasis and homeorhesis. J. Dairy Sci. 63:1514-1529.

Bauman, D. E., K. J. Harvatine, and A. L. Lock. 2011. Nutrigenomics, rumen-derived bioactive fatty acids, and the regulation of milk fat synthesis. Annu. Rev. Nutr. 31:299-319.

Bauman, D. E., J. W. Perfield, K. J. Harvatine, and L. H. Baumgard 2008. Regulation of fat synthesis by conjugated linoleic acid: Lactation and the ruminant model. J. Nutr. 138:403-409.

Baumgard, L. H., E. Matitashvili, B. A. Corl, D. A. Dwyer, and D. E. Bauman. 2002. trans-10, cis-12 conjugated linoleic acid decreases lipogenic rates and expression of genes involved in milk lipid synthesis in dairy cows. J. Dairy Sci. 85:2155-2163.

Bequette, B. J., C. E. Kyle, L. A. Crompton, V. Buchan, and M. D. Hanigan. 2001. Insulin regulates milk production and mammary gland and hind-leg amino acid fluxes and blood flow in lactating goats. J. Dairy Sci. 84:241-255.

Bernard, L., C. Leroux, and Y. Chilliard. 2008. Expression and nutritional regulation of lipogenic genes in the ruminant lactating mammary gland. Adv. Exp. Med. Biol. 606:67-108.

Castañeda-Gutiérrez, E., B. C. Benefield, M. J. de Veth, N. R. Santos, R. O. Gilbert, W. R. Butler, and D. E. Bauman. 2007. Evaluation of the mechanism of action of conjugated linoleic acid isomers on reproduction in dairy cows. J. Dairy Sci. 90:4253-4264.

de Andrade, P. V. D., and P. Schmidely. 2011. Milk composition during duodenal infusion of conjugated linoleic acid in dairy goats fed diets with different C18:2/C18:1 ratios. Arq. Bras. Med. Vet. Zootec. 63:1272-1276.

de Veth, M. J., E. Castañeda-Gutiérrez, D. A. Dwyer, A. M. Pfeiffer, D. Putnam, and D. E. Bauman. 2006. Response to conjugated linoleic acid in dairy cows differing in energy and protein status. J. Dairy Sci. 89:4620-4631.

Fernandez, J. M., T. Sahlu, C. D. Lu, D. Ivey, and M. J. Potchoiba. 1997. Production and metabolic aspects of nonprotein nitrogen incorporation in lactation rations of dairy goats. Small Rumin. Res. 26:105-117.

Folch, J., M. Lees, and G. H. S. Stanley. 1957. A simple method for the isolation and purification of total lipids from animal tissues. J. Biol. Chem. 226:497-509.

Gervais, R., J. W. McFadden, A. J. Lengi, B. A. Corl, and P. Y. Chouinard. 2009. Effects of intravenous infusion of trans-10, cis-12 18:2 on mammary lipid metabolism in lactating dairy cows. J. Dairy Sci. 92:5167-5177.

Ghazal, S., V. Berthelot, N. C. Friggens, and P. Schmidely. 2012. Influence of a supplement containing conjugated linoleic acid on dairy performance, milk fatty acid composition, and adipose tissue reactivity to lipolytic challenge in mid-lactation goats. J. Dairy Sci 95:7308-7318

Glasser, F., M. Doreau, A. Ferlay, and Y. Chilliard. 2007. Technical note: Estimation of milk fatty acid yield from milk fat data. J. Dairy Sci. 90:2302-2304.

Glasser, F., P. Schmidely, D. Sauvant, and M. Doreau. 2008. Digestion of fatty acids in ruminants: A meta-analysis of flows and variation factors: 2. C18 fatty acids. Animal 2:691-704.

Harvatine, K. J., and D. E. Bauman. 2006. SREBP1 and thyroid hormone responsive spot 14 (S14) are involved in the regulation of 
bovine mammary lipid synthesis during diet-induced milk fat depression and treatment with CLA. J. Nutr. 136:2468-2474.

Harvatine, K. J., J. W. Perfield II, and D. E. Bauman. 2009. Expression of enzymes and key regulators of lipid synthesis is up regulated in adipose tissue during CLA-induced milk fat depression in dairy cows. J. Nutr. 139:849-854.

Hussein, M., K. H. Harvatine, W. M. P. B. Weerasinghe, L. A. Sinclair, and D. E. Bauman. 2013. Conjugated linoleic acid-induced milk fat depression in lactating ewes is accompanied by reduced expression of mammary genes involved in lipid synthesis. J. Dairy Sci. 96:3825-3834.

INRA (Institut National de la Recherche Agronomique). 2007. Alimentation des bovins, ovins et caprins. Besoins des animaux - Valeurs des aliments. Éditions Quae, Versailles, France.

ISO (International Organization for Standardization). 1999. Animal feeding stuffs - Determination of moisture and other volatile matter content. ISO 6496. ISO, Geneva, Switzerland.

ISO (International Organization for Standardization). 2002. Animal feeding stuffs - Determination of crude ash. ISO 5984. ISO, Geneva, Switzerland.

ISO (International Organization for Standardization). 2004. Animal feeding stuffs - Enzymatic determination of total starch content. ISO 15914. ISO, Geneva, Switzerland.

Jenkins, T. C., R. J. Wallace, P. J. Moate, and E. E. Mosley. 2008. Board-Invited Review: Recent advance in biohydrogenation of unsaturated fatty acids within the rumen microbial ecosystem. J. Anim. Sci. 86:397-412.

Kay, J. K., J. R. Roche, C. E. Moore, and L. H. Baumgard. 2006. Effects of dietary conjugated linoleic acid production and metabolic parameters in transition dairy cows grazing fresh pasture. J. Dairy Res. 73:367-377.

Lapierre, H., G. E. Lobley, L. Doepel, G. Raggio, H. Rulquin, and S. Lemosquet. 2012. Mammary metabolism of amino acids in dairy cows. J. Anim. Sci. 90:1708-1721.

LeDoux, M., A. Rouzeau, P. Bas, and D. Sauvant. 2002. Occurrence of trans- $\mathrm{C}_{18: 1}$ fatty acid isomers in goat milk: Effect of two dietary regimens. J. Dairy Sci. 85:190-197.

Lock, A. L., M. Rovai, T. A. Gipson, M. J. de Veth, and D. E. Bauman. 2008. A conjugated linoleic acid supplement containing trans-10, cis-12 conjugated linoleic acid reduces milk fat synthesis in lactating goats. J. Dairy Sci. 91:3291-3299.

Lourenço, M., E. Ramos-Morales, and R. J. Wallace. 2010. The role of microbes in rumen lipolysis and biohydrogenation and their manipulation. Animal 4:1008-1023.

Maxin, G., F. Glasser, C. Hurtaud, J. L. Peyraud, and H. Rulquin. 2011. Combined effects of trans-10,cis-12 conjugated linoleic acid, propionate, and acetate on milk fat yield and composition in dairy cows. J. Dairy Sci. 94:2051-2059.

Maxin, G., F. Glasser, and H. Rulquin. 2010. Additive effects of trans-10, cis-12 conjugated linoleic acid and propionic acid on milk fat content and composition in dairy cows. J. Dairy Res. $77: 295-301$

Pappritz, J., P. Lebzien, U. Meyer, G. Jahreis, R. Kramer, G. Flachowsky, and S. Dänicke. 2011. Duodenal availability of conju- gated linoleic acids after supplementation to dairy cow diets. Eur. J. Lipid Sci. Technol. 113:1443-1455.

Perfield, J. W., II, A. L. Lock, A. M. Pfeiffer, and D. E. Bauman. 2004. Effects of amide-protected and lipid-encapsulated Conjugated Linoleic Acid (CLA) supplements on milk fat synthesis . J. Dairy Sci. 87:3010-3016.

Peterson, D. G., E. A. Matitashvili, and D. E. Bauman. 2004. The inhibitory effect of trans-10, cis-12 CLA on lipid synthesis in bovine mammary epithelial cells involves reduced proteolytic activation of the transcription factor SREBP-1. J. Nutr. 134:2523-2527.

Qiu, X., M. L. Eastridge, K. E. Griswold, and J. L. Firkins. 2004. Effects of substrate, passage rate, and $\mathrm{pH}$ in continuous culture on flows of conjugated linoleic acid and trans C18:1. J. Dairy Sci. 87:3473-3479.

Schmidely, P., F. Meschy, J. Tessier, and D. Sauvant. 2002. Lactation response and nitrogen, calcium, and phosphorus utilization of dairy goats differing by the genotype for $\alpha_{\mathrm{S} 1}$-casein in milk, and fed diets varying in crude protein concentration. J. Dairy Sci. 85:2299-2307.

Shingfield, K. J., L. Bernard, C. Leroux, and Y. Chilliard. 2010. Role of trans fatty acids in the nutritional regulation of mammary lipogenesis in ruminants. Animal 4:1140-1166.

Shingfield, K. J., J. Rouel, and Y. Chilliard. 2009. Effect of calcium salts of a mixture of conjugated linoleic acids containing trans-10, cis-12 in the diet on milk fat synthesis in goats. Br. J. Nutr. 101:1006-1019.

Sinclair, L. A., A. L. Lock, R. Early, and D. E. Bauman. 2007. Effects of trans-10, cis-12 conjugated linoleic acid on ovine milk fat synthesis and cheese properties. J. Dairy Sci. 90:3326-3335.

Sinclair, L. A., W. M. P. B. Weerasinghe, R. G. Wilkinson, M. J. de Veth, and D. E. Bauman. 2010. A supplement containing trans-10, cis-12 conjugated linoleic acid reduces milk fat yield but does not alter organ weight or body fat deposition in lactating ewes. J. Nutr. 140:1949-1955.

Van Soest, P. J., J. B. Robertson, and B. A. Lewis. 1991. Methods for dietary fiber, neutral detergent fiber, and nonstarch polysaccharides in relation to animal nutrition. J. Dairy Sci. 74:3583-3597.

von Soosten, D.. U. Meyer, M. Piechotta, G. Flachowsky, and S. Dänicke. 2012. Effect of conjugated linoleic acid supplementation on body composition, body fat mobilization, protein accretion, and energy utilization in early lactation dairy cows. J. Dairy Sci. 95:1222-1239.

von Soosten, D., U. Meyer, E. M. Weber, J. Rehage, G. Flachowsky, and S. Dänicke. 2011. Effect of trans-10, cis-12 conjugated linoleic acid on performance, adipose depot weights, and liver weight in early-lactation dairy cows. J. Dairy Sci. 94:2859-2870.

Weerasinghe, W. M. P. B., R. G. Wilkinson, A. L. Lock, M. J. de Veth, D. E. Bauman, and L. A. Sinclair. 2012. Effect of a supplement containing trans-10,cis-12 conjugated linoleic acid on the performance of dairy ewes fed 2 levels of metabolizable protein and at a restricted energy intake. J. Dairy Sci. 95:109-116. 
Table A1. Milk FA profile ( $\mathrm{g} / 100 \mathrm{~g}$ of milk fat) in lactating goats fed $45 \mathrm{~g}$ of Ca salts of palm oil/d [control (CTL)] or $45 \mathrm{~g}$ of CLA/d (4.5 g of trans-10,cis-12 C18:2 + $4.5 \mathrm{~g}$ of cis-9,trans-11 C18:2) at 2 feeding levels [FL; 100 vs. 85\% of energy requirements (FL100 vs. FL85, respectively) $]^{1}$

\begin{tabular}{|c|c|c|c|c|c|c|c|c|c|c|c|}
\hline \multirow[b]{2}{*}{ FA, g/100 g } & \multicolumn{4}{|c|}{$\mathrm{FL}$} & \multirow[b]{2}{*}{ SEM } & \multicolumn{6}{|c|}{$P$-value } \\
\hline & $\begin{array}{c}\text { CTL } \\
(\mathrm{n}=6)\end{array}$ & $\begin{array}{c}\text { CLA } \\
(\mathrm{n}=6)\end{array}$ & $\begin{array}{c}\text { CTL } \\
(\mathrm{n}=6)\end{array}$ & $\begin{array}{c}\text { CLA } \\
(\mathrm{n}=6)\end{array}$ & & FL & CLA & $\begin{array}{l}\text { CLA } \\
\times \text { FL }\end{array}$ & $\begin{array}{c}\text { Time } \\
(\mathrm{T})\end{array}$ & $\begin{array}{l}\text { CLA } \\
\times \mathrm{T}\end{array}$ & $\begin{array}{l}\mathrm{FL} \\
\times \mathrm{T}\end{array}$ \\
\hline C4:0 & $2.00^{\mathrm{a}}$ & $2.43^{\mathrm{b}}$ & $2.13^{\mathrm{a}}$ & $2.53^{\mathrm{b}}$ & 0.068 & 0.54 & 0.03 & 0.93 & 0.11 & 0.97 & 0.94 \\
\hline C6:0 & 2.73 & 2.71 & 2.81 & 2.69 & 0.049 & 0.82 & 0.53 & 0.61 & $<0.001$ & 0.05 & 0.20 \\
\hline C11:0 & $0.24^{\mathrm{a}}$ & $0.14^{\mathrm{b}}$ & $0.24^{\mathrm{a}}$ & $0.15^{\mathrm{b}}$ & 0.010 & 0.75 & 0.01 & 0.50 & 0.006 & 0.68 & 0.40 \\
\hline $\mathrm{C} 12: 0$ & 4.01 & 4.01 & 4.55 & 3.91 & 0.178 & 0.36 & 0.17 & 0.18 & $<0.001$ & 0.02 & 0.40 \\
\hline $\mathrm{C} 13: 0$ & $0.11^{\mathrm{a}}$ & $0.09^{\mathrm{ab}}$ & $0.12^{\mathrm{a}}$ & $0.08^{\mathrm{b}}$ & 0.006 & 0.88 & 0.005 & 0.20 & 0.004 & 0.14 & 0.48 \\
\hline iso $\mathrm{C} 14: 0$ & $0.06^{\mathrm{a}}$ & $0.08^{\mathrm{b}}$ & $0.06^{\mathrm{a}}$ & $0.09^{\mathrm{b}}$ & 0.005 & 0.64 & $<0.001$ & 0.82 & 0.05 & 0.71 & 0.26 \\
\hline $\mathrm{C} 14: 0$ & $9.42^{\mathrm{a}}$ & $10.40^{\mathrm{b}}$ & $10.13^{\mathrm{ab}}$ & $10.50^{\mathrm{b}}$ & 0.176 & 0.17 & 0.04 & 0.34 & 0.35 & 0.89 & 0.15 \\
\hline cis-9 C14:1 & $0.09^{\mathrm{a}}$ & $0.06^{\mathrm{b}}$ & $0.08^{\mathrm{a}}$ & $0.06^{\mathrm{b}}$ & 0.006 & 0.89 & 0.003 & 0.51 & 0.21 & 0.95 & 0.49 \\
\hline iso $\mathrm{C} 15: 0$ & $0.11^{\mathrm{a}}$ & $0.15^{\mathrm{b}}$ & $0.15^{\mathrm{b}}$ & $0.15^{\mathrm{b}}$ & 0.005 & 0.03 & 0.02 & 0.02 & 0.47 & 0.78 & 0.65 \\
\hline trans-9 C16:1 & 0.23 & 0.30 & 0.17 & 0.16 & 0.017 & 0.07 & 0.40 & 0.25 & 0.84 & 0.35 & 0.76 \\
\hline iso $\mathrm{C} 17: 0$ & 0.28 & 0.33 & 0.29 & 0.32 & 0.010 & 0.95 & 0.13 & 0.71 & 0.27 & 0.72 & 0.85 \\
\hline $\mathrm{C} 17: 0$ & 0.52 & 0.54 & 0.56 & 0.56 & 0.013 & 0.30 & 0.73 & 0.87 & 0.10 & 0.12 & 0.57 \\
\hline C18:0 & $6.67^{\mathrm{a}}$ & $11.48^{\mathrm{b}}$ & $8.47^{\mathrm{a}}$ & $12.08^{\mathrm{b}}$ & 0.371 & 0.02 & $<0.001$ & 0.18 & 0.02 & 0.18 & 0.48 \\
\hline cis-9 C18:1 & $13.15^{\mathrm{a}}$ & $10.14^{\mathrm{b}}$ & $13.76^{\mathrm{a}}$ & $12.21^{\mathrm{a}}$ & 0.495 & 0.14 & 0.02 & 0.42 & 0.02 & 0.63 & 0.71 \\
\hline cis-11 C18:1 & 0.52 & 0.48 & 0.44 & 0.46 & 0.012 & 0.08 & 0.46 & 0.31 & $<0.001$ & 0.13 & 0.71 \\
\hline cis-12 C18:1 & 0.32 & 0.28 & 0.29 & 0.40 & 0.015 & 0.08 & 0.21 & 0.01 & 0.09 & 0.53 & 0.95 \\
\hline cis-13 C18:1 & 0.08 & 0.07 & 0.07 & 0.06 & 0.002 & 0.23 & 0.06 & 0.17 & 0.38 & 0.11 & 0.75 \\
\hline cis-15 C18:1 & $0.07^{\mathrm{a}}$ & $0.06^{\mathrm{b}}$ & $0.06^{\mathrm{b}}$ & $0.05^{\mathrm{b}}$ & 0.0019 & 0.03 & 0.008 & 0.52 & 0.37 & 0.004 & 0.51 \\
\hline trans-6,-7,-8 C18:1 & $0.41^{\mathrm{a}}$ & $0.39^{\mathrm{a}}$ & $0.32^{\mathrm{b}}$ & $0.31^{\mathrm{b}}$ & 0.012 & 0.007 & 0.75 & 0.80 & 0.20 & 0.89 & 0.83 \\
\hline trans-9 C18:1 & $0.34^{\mathrm{a}}$ & $0.31^{\mathrm{ab}}$ & $0.28^{\mathrm{b}}$ & $0.28^{\mathrm{b}}$ & 0.007 & 0.005 & 0.51 & 0.34 & 0.03 & 0.35 & 0.76 \\
\hline trans-10 C18:1 & 1.20 & 0.83 & 0.67 & 0.65 & 0.078 & 0.16 & 0.42 & 0.47 & 0.14 & 0.27 & 0.97 \\
\hline trans-11 C18:1 & $2.27^{\mathrm{a}}$ & $3.43^{\mathrm{b}}$ & $1.53^{\mathrm{c}}$ & $1.58^{\mathrm{bc}}$ & 0.198 & 0.0001 & 0.05 & 0.13 & 0.84 & 0.16 & 0.56 \\
\hline trans-12 C18:1 & $0.40^{\mathrm{a}}$ & $0.38^{\mathrm{a}}$ & $0.35^{\mathrm{b}}$ & $0.41^{\mathrm{a}}$ & 0.008 & 0.53 & 0.26 & 0.05 & 0.78 & 0.07 & 0.49 \\
\hline cis-9,cis-12,cis-15 C18:3 & 0.30 & 0.29 & 0.28 & 0.30 & 0.009 & 0.80 & 0.73 & 0.25 & 0.13 & 0.31 & 0.68 \\
\hline C19:0 & 0.11 & 0.10 & 0.10 & 0.12 & 0.003 & 0.47 & 0.85 & 0.22 & 0.09 & 0.24 & 0.40 \\
\hline C20:0 & $0.10^{\mathrm{a}}$ & $0.13^{\mathrm{b}}$ & $0.12^{\mathrm{ab}}$ & $0.15^{\mathrm{c}}$ & 0.006 & 0.02 & $<0.001$ & 0.90 & 0.04 & 0.39 & 0.34 \\
\hline
\end{tabular}

${ }^{\mathrm{a}-\mathrm{C}}$ Values within a row with different superscript letters differ at least at the $P<0.05$ level of significance.

${ }^{1}$ Values represent LSM, with data obtained during wk 3 used as covariates.

${ }^{2} \mathrm{ND}=$ not detectable. 